\title{
Bull Trout Population and Habitat Surveys in the Middle Fork Willamette and McKenzie Rivers
}

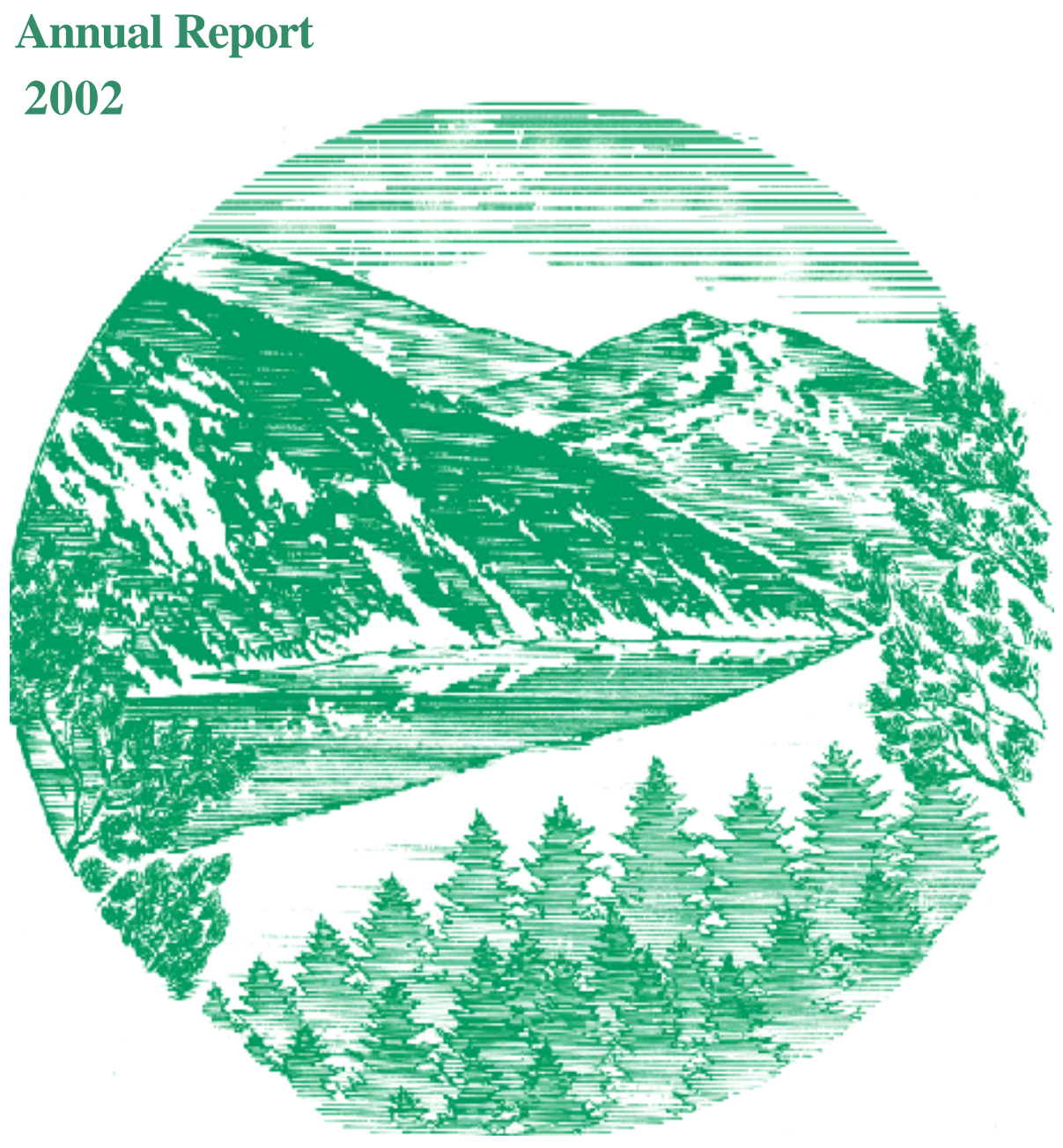

DOE/BP-00004093-3

October 2003 
This Document should be cited as follows:

Seals, Jason, Kelly Reis, "Bull Trout Population and Habitat Surveys in the Middle Fork

Willamette and McKenzie Rivers", Project No. 1994-05300, 30 electronic pages, (BPA

Report DOE/BP-00004093-3)

Bonneville Power Administration

P.O. Box 3621

Portland, Oregon 97208

This report was funded by the Bonneville Power Administration (BPA), U.S. Department of Energy, as part of BPA's program to protect, mitigate, and enhance fish and wildlife affected by the development and operation of hydroelectric facilities on the Columbia River and its tributaries. The views in this report are the author's and do not necessarily represent the views of BPA. 


\title{
BULL TROUT POPULATION AND HABITAT SURVEYS IN THE MIDDLE FORK WILLAMETTE AND MCKENZIE RIVERS
}

\author{
ANNUAL REPORT
}

2002

\author{
Prepared By: \\ Jason Seals \\ Kelly Reis
}

Funded By:

U. S. Department of Energy

Bonneville Power Administration

Environment, Fish and Wildlife

P.O. Box 3621

Portland, OR 97208-3621

Project Number: 1994-053-00

Contract Number: 00004093 


\section{CONTENTS}

$\underline{\text { Page }}$

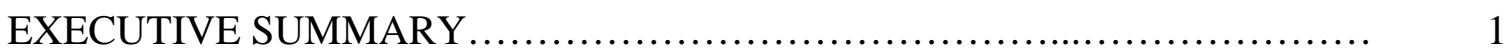

Objectives..................................................... 1

Accomplishments and Findings.................................. 1

Management Recommendations................................... 1

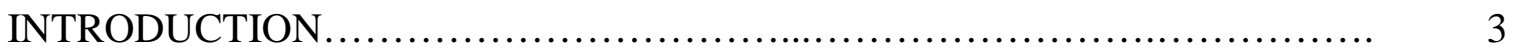

STUDY AREA DESCRIPTION.......................................... 4

METHODS ................................................................ 6

Anderson Creek Screw Trap....................................... 6

Middle Fork Willamette Re-Introduction........................... 6

Middle Fork Willamette Population Monitoring..................... 6

Vaki Riverwatcher Fishcounter and Video Analysis in Anderson Creek,

Roaring River, and Ollalie Creek................................... 7

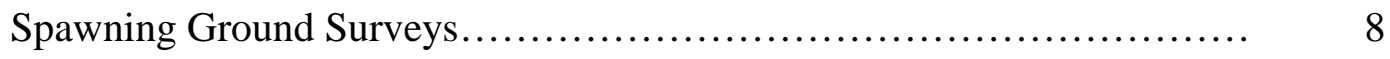

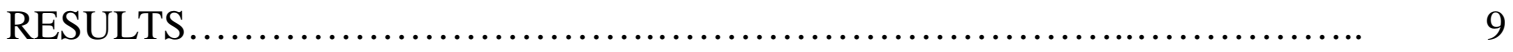

Anderson Creek Screwtrap..................................... 9

Middle Fork Willamette Re-Introduction.......................... 9

Middle Fork Willamette Population Monitoring..................... 11

Vaki Riverwatcher Fishcounter and Video Analysis in Anderson Creek, Roaring River, and Ollalie Creek.................................. 11

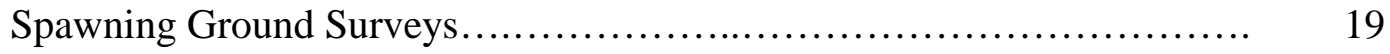

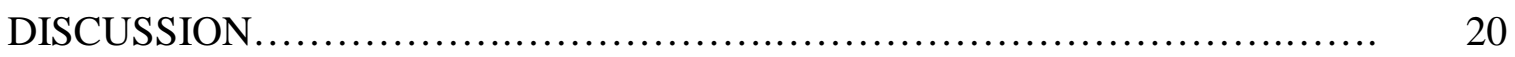

ACKNOWLEDGEMENTS ............................................. 21 


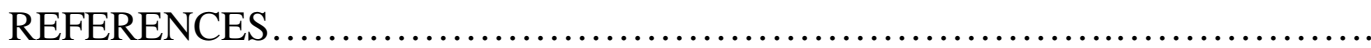

APPENDIX A. Standard Pool Counts......................................... 23 


\section{FIGURES}

Number

$\underline{\text { Page }}$

1. Map of the McKenzie and Middle Fork Willamette Rivers....................

2. Number of fry and juvenile bull trout caught in the Anderson Creek

3. Length frequency distribution of bull trout passing upstream through the Vaki Riverwatcher in Anderson Creek from 1999 to 2002

4. Length frequency distribution of bull trout passing upstream through the Vaki Riverwatcher in Roaring River from 1999 to 2002

5. Diel movement of bull trout through the Vaki Riverwatcher in Anderson Creek during the 2002 migration period

6. Diel movement of bull trout through the Vaki Riverwatcher in Roaring River during the 2002 migration period.

7. Migration timing of bull trout through the Vaki Riverwatcher in

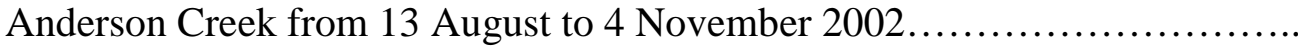

8. Migration timing of bull trout through the Vaki Riverwatcher in

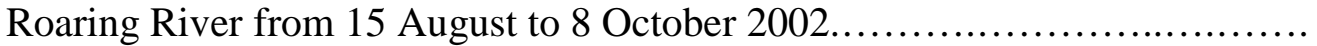




\section{TABLES}

Number

$\underline{\text { Page }}$

1. Date, location, and number of minnow traps placed in tributaries of the Middle Fork Willamette in 2002.

2. Bull trout redd survey location, distance (if applicable), and dates each location was surveyed in 2002

3. The number of bull trout fry and juveniles $(1+$ and older $)$ captured in the downstream migrant screwtrap in Anderson Creek from 1994 to 2001

4. Location and number of bull trout fry transferred from Anderson Creek to release sites in the Middle Fork Willamette above Hills Creek Reservoir from 1997 to 2002.

5. The total number of upstream adult bull trout migrants counted by a Vaki in Anderson Creek and Roaring River from 1999 to 2002, and in Olallie Creek in 2002

6. Estimated range and mean length in millimeters of bull trout passing upstream of a Vaki Riverwatcher Fishcounter in Anderson Creek, Roaring River, and Olallie Creek in 2002

7. The year and number of bull trout redds enumerated in Anderson Creek, Olallie Creek, main stem McKenzie River, Sweetwater Creek, and Roaring River... 


\section{EXECUTIVE SUMMARY}

\section{Project Objectives}

1. Determine distribution and life history characteristics of bull trout in the Middle Fork Willamette and McKenzie basins.

2. Estimate the abundance of bull trout in the Middle Fork Willamette and McKenzie basins.

3. Implement the Rehabilitation of the Middle Fork Willamette Bull Trout Population, Risk Analysis and Monitoring Plan (ODFW 1998).

4. Provide information acquired about bull trout to landowners and land management agencies within the McKenzie and Middle Fork Willamette basins and to other regional entities.

5. Improve public awareness about the status and distribution of bull trout in the McKenzie and Middle Fork Willamette basins.

\section{Accomplishments and Findings}

Juvenile bull trout were sampled by rotary screw trap in Anderson Creek during downstream emigration. We captured 508 bull trout fry (Age 0 ) and 131 age 1 and older juvenile bull trout from 12 February to 14 August, 2002. We estimate 1453 fry and 397 age 1 and older bull trout passed the trap site in Anderson Creek in 2002. Minnow traps set in tributaries of the Middle Fork Willamette captured 2 bull trout in Shadow Springs, 1 bull trout in Found Creek, and 1 bull trout in Indigo Springs. A Vaki Riverwatcher Fishcounter enumerated 287 bull trout moving upstream in Anderson Creek, 82 bull trout moving upstream in Roaring River, and 10 bull trout moving upstream in Olallie Creek during the 2002 spawning migration. Bull trout redd surveys were conducted during August, September, and October, 2002. We observed 60 redds in Anderson Creek, 10 redds in Olallie Creek, 3 redds in the McKenzie River above Trail Bridge Reservoir, 1 redd in Sweetwater Creek, and 25 redds in Roaring River for a total of 99 redds in the McKenzie Basin.

\section{Management Recommendations}

1. Increase survival potential of the current bull trout populations by continuing to set restrictive angling regulations that require catch and release of all wild trout and allow the use of artificial flies and lures only.

2. Consider reducing angling pressure where bull trout exist by discontinuing stocking of hatchery trout. 
3. Continue to adipose fin mark all rainbow trout released into areas where bull trout exist to reduce angler misidentification.

4. Investigate the seasonal distribution, spawning distribution, redd densities, and abundance of adult bull trout in the Middle Fork Willamette River to further monitor the results of the bull trout re-introduction project.

5. Increase public awareness and education about bull trout by posting information and road signs near bull trout water-bodies and speaking to area angling groups about bull trout life history and conservation. 


\section{INTRODUCTION}

Bull trout in the Willamette River Basin were historically distributed throughout major tributaries including the Middle Fork Willamette and McKenzie rivers. Habitat degradation, over-harvest, passage barriers, fish removal by rotenone, and hybridization and competition with non-native brook trout are all likely factors that have led to the decline of bull trout in the Willamette Basin (Ratliff and Howell 1992). The U.S. Fish and Wildlife Service listed the Columbia River bull trout population segment as Threatened under the federal Endangered Species Act in 1998. Four bull trout populations were isolated in the upper Willamette River following the construction of flood control dams on the South Fork McKenzie River, McKenzie River, and Middle Fork Willamette River that created Cougar, Trail Bridge, and Hills Creek reservoirs. Buchanan et al. (1997) described the population in the main stem McKenzie as "of special concern", the South Fork McKenzie population as "high risk of extinction," the population above Trail Bridge Reservoir as "high risk of extinction," and bull trout in the Middle Fork Willamette as "probably extinct." Various management efforts such as strict angling regulations and passage improvement projects have been implemented to stabilize and rehabilitate bull trout habitat and populations in the McKenzie River over the past 10 years. Since 1997, bull trout fry from Anderson Creek on the upper McKenzie River have been transferred to the Middle Fork Willamette basin above Hills Creek Reservoir in an attempt to re-establish a reproducing bull trout population.

This project was developed in response to concerns over the population status and management of bull trout in the McKenzie and Middle Fork Willamette Rivers by the Oregon Department of Fish and Wildlife during the early 1990s. The project was conducted under measure 9.3G(2) of the Columbia Basin Fish and Wildlife Program to

monitor the status, life history, habitat needs, and limiting factors for bull trout within sub basins of the Columbia River. Also, this project provides information to develop native fish recovery plans such as the Oregon Plan for Salmon and Watersheds and the U.S. Fish and Wildlife Bull Trout Recovery Plan. 


\section{STUDY AREA}

The McKenzie basin drains an area of approximately $3300 \mathrm{~km}^{2}$ on the western slope of the Cascade Mountains in Oregon. The McKenzie River (hereafter may be referred to as

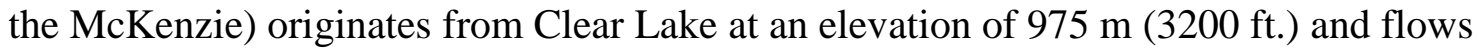
about 145 river kilometers (rkm) to its confluence with the Willamette River. Bull trout are seasonally distributed in the main stem McKenzie from the mouth (rkm 0) to Tamolich Falls (rkm 120), however, most bull trout reside year round upstream of rkm 62. Anderson Creek, Olallie Creek, Sweetwater Creek, and the main stem McKenzie above Trailbridge Reservoir are the primary spawning areas used by bull trout in the upper McKenzie basin.

Bull Trout are also found in the South Fork of the McKenzie River (hereafter may be referred to as the South Fork) from Cougar Dam to about the Three Sisters Wilderness Boundary (rkm 42). The South Fork joins the McKenzie at rkm 95. Roaring River is the only known spawning area for bull trout in the South Fork.

The Middle Fork Willamette River (hereafter may be referred to as the Middle Fork) drains an area of about $3450 \mathrm{~km}^{2}$ and originates near Timpanogas Lake in the Cascade Mountains at an elevation of $1663 \mathrm{~m}$ (5400 ft.). It flows northwesterly $134 \mathrm{rkm}$ where it joins the Coast Fork of the Willamette River near the city of Eugene to form the Willamette River. The bull trout rehabilitation area of the Middle Fork is located from Hills Creek Reservoir upstream to rkm 116. Release sites for juvenile bull trout include Iko Springs, Chuckle Springs, Indigo Springs, Shadow Springs, Bear Creek, Found Creek, Skunk Creek, Echo Creek and Swift Creek. 

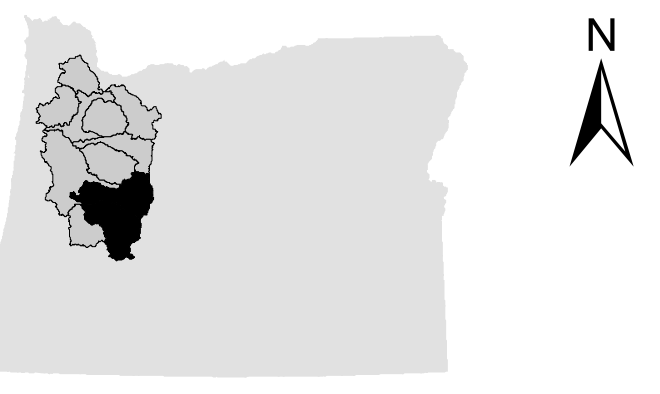

\section{Upper McKenzie Population}
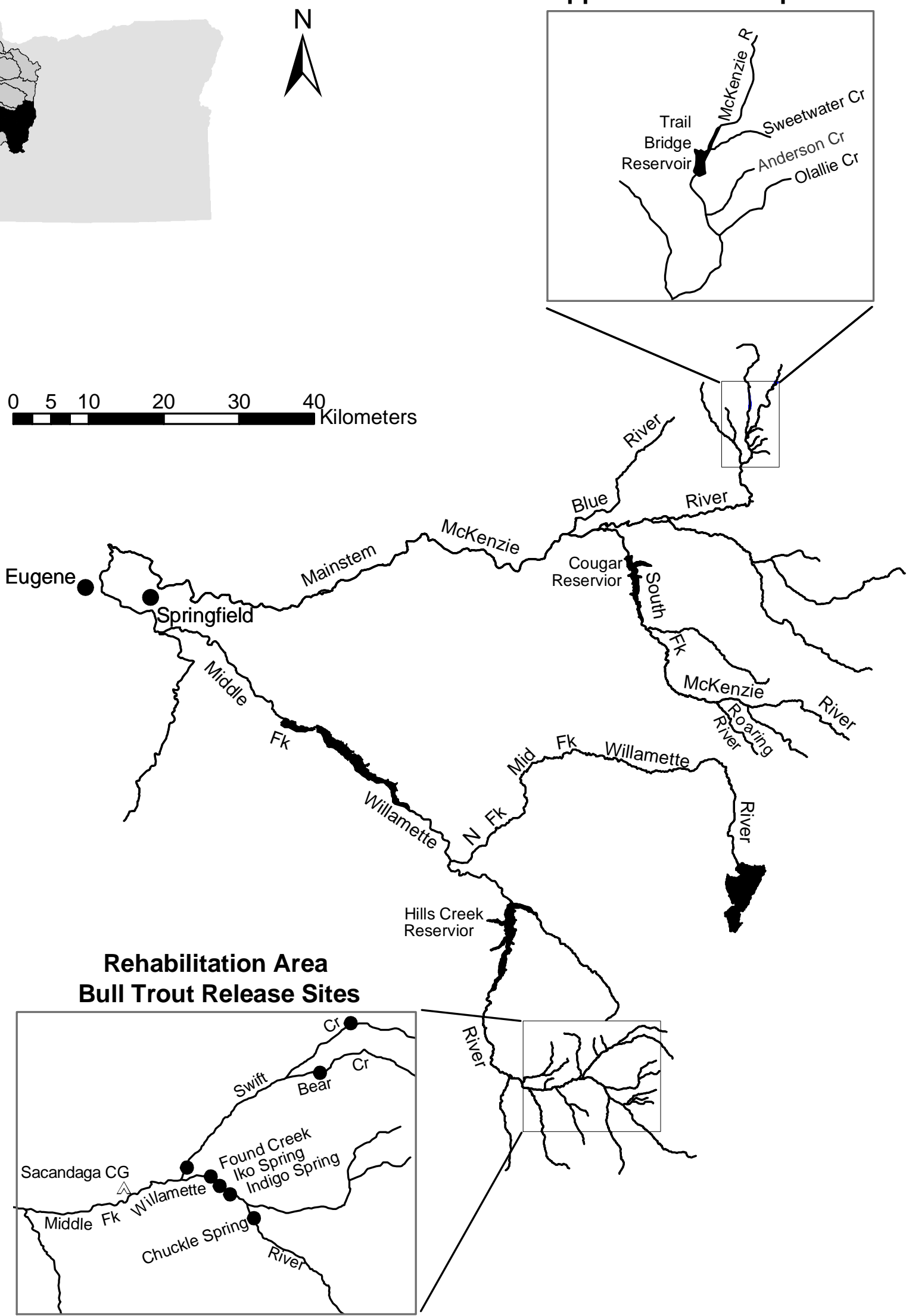

Figure 1. Map of the McKenzie and Middle Fork Willamette Rivers. Boxes denote key study areas. 


\section{METHODS}

\section{Anderson Creek Screw Trap}

The McKenzie River Ranger District operated a 1.52 m (5 ft.) diameter rotary screw trap in Anderson Creek from 12 February to 31 May 2002. The screw trap was located in outflow created by U.S. 126 culvert approximately 0.4 rkm upstream from the confluence with the McKenzie and was in operation four days each week. This trap was used to assess the abundance and timing of bull trout fry (age 0) leaving Anderson Creek during emigration. Additionally, this trap allows us to monitor age 1 and older juvenile (age 1+) bull trout abundance and migration trends in Anderson Creek.

Juvenile bull trout age 0 and age $1+$ escapements were estimated by extrapolating the actual 4-day weekly catch into an expanded 7-day weekly catch (if the trap were operated 7 days a week), and calculating a total escapement estimate based on 60\% trap efficiency. Escapement (E) was estimated using the following equation:

$$
\mathrm{E}=\mathrm{WC} / 0.6 \text {, }
$$

where WC is the total of weekly-expanded catch estimates and 0.6 is the $60 \%$ trap efficiency.

Trap efficiency was estimated in previous years using chinook fry and marked age $1+$ bull trout. Trap efficiency was consistently estimated at $60 \%$ for fry and age $1+$ bull trout. Because flows are uniform in Anderson Creek and the trap has not been moved from it's attachment to the culvert, we assume trap efficiency has not changed from our previous estimate of $60 \%$.

\section{Middle Fork Willamette Re-Introduction}

Bull trout fry captured from the Anderson Creek screw trap were transferred into the bull trout rehabilitation area of the Middle Fork Willamette River in March and April. Less than $25 \%$ of the fry captured per week were transferred to release sites on the Middle Fork (ODFW 1997). Release sites were chosen and prioritized before trapping season began. Fry were transferred to the Middle Fork in a 150 gallon oxygenated fish transport tank. Fry were taken to release sites in a 5 gallon bucket where they were released into suitable pockets of habitat.

\section{Middle Fork Willamette Population Monitoring}

Minnow traps were set in tributaries of the Middle Fork near fry release sites to monitor juvenile presence and distribution in the rehabilitation area. Surveyors placed 7-40 traps baited with salmon eggs into Indigo Springs, Shadow Springs, Found Creek, Bear Creek, and Swift Creek on various days (Table1). Traps were fished over night usually for a period of 20-24 hours. Bull trout captured were anesthetized with MS 222 while length and weight were recorded. 
We snorkeled a series of standard pools to assess relative abundance and distribution of adult and juvenile bull trout in the main stem Middle Fork above Hills Creek Reservoir. Pools were selected based on counts conducted in previous years. Surveys occurred during daylight hours once a week between 5 June and 22 July. One night dive occurred on 31 July.

Table 1. Date, location, and number of minnow traps set in tributaries of the Middle Fork in 2002.

\begin{tabular}{clc}
\hline Date & \multicolumn{1}{c}{ Tributary } & Number of Traps \\
\hline $5 / 30$ & Found Creek & 40 \\
& Indigo Springs & 20 \\
$6 / 6$ & Above culvert & 20 \\
$6 / 12$ & Side Channel & 10 \\
$7 / 18$ & Shadow Springs & 7 \\
$7 / 31$ & Bear Creek & 10 \\
$7 / 31$ & Swift Creek & \\
\hline
\end{tabular}

\section{Vaki Riverwatcher Fishcounter and Video Analysis in Anderson Creek, Roaring River, and Olallie Creek}

To estimate the number and size of bull trout migrating into Anderson Creek, Olallie Creek, and Roaring River during the spawning season, we installed a temporary weir and a passively triggered fish counter in each stream. The electronic fish counter (Vaki Riverwatcher) is a counter that emits infrared light beams that are interrupted when objects pass through a field. A computer produces an electronic silhouette of the object. The Riverwatcher unit records the date, time, water temperature, direction, length, and body depth of each fish passing upstream or downstream. Migration was monitored from 13 August to 4 November in Anderson Creek, 2 August to 9 October in Ollalie Creek, and 16 August to 8 October in Roaring River. Routine maintenance performed for each counting station included removing debris from the weir, changing batteries, and uploading data. These activities were a collaborative effort between ODFW McKenzieWillamette Bull Trout Project, McKenzie River Ranger District (USFS), and ODFW Cougar Reservoir-South Fork McKenzie River Bull Trout Research Project.

The Riverwatcher measures the height of an object to estimate length by using a length to depth ratio. In 2002, we used a length to depth ratio of 4.6:1 in Anderson Creek, 5.1:1 in Roaring River, and 4.6:1 in Olallie Creek to estimate the approximate length of bull trout passing through the Riverwatcher. Measurements from 2 McKenzie display specimens estimated the ratio of 4.6:1 for Anderson and Olallie Creeks. Measurements from bull trout captured in the South Fork estimated the ratio at 5.1:1 for Roaring River. We feel these ratios represent the body depth to length ratio of bull trout more accurately than the default ratio suggested by the Riverwatcher at 6:1. We will continue to use 4.6:1 in Anderson and Olallie Creeks until we can measure more bull trout to refine the ratio.

We report the number fish detected by the Riverwatcher with a estimated length greater than $180 \mathrm{~mm}$. This minimum was used assuming sexual mature bull trout should be greater than $180 \mathrm{~mm}$ and fish recorded smaller than $180 \mathrm{~mm}$ were not sexually mature bull trout or possibly a different species. 
A black and white underwater video camera was installed on Anderson Creek just upstream of the Vaki to confirm fish counted on the Vaki were bull trout. The video was in operation from 5 September to 4 October. USFS and ODFW installed the camera beneath an undercut bank. We were unable to install lights to monitor movement at night.

\section{Bull Trout Spawning Ground Surveys}

Bull trout redd counts were conducted during August, September, and October and encompassed primary spawning areas or areas suspected to have spawning activity. Sections within these areas (Roaring River, Sweetwater Creek, Anderson Creek, Ollalie Creek, and main stem McKenzie) were established as index surveys to develop information on relative abundance trends in bull trout redds. Bull trout typically spawn during September and October (Goetz 1994 A), therefore, surveys are scheduled multiple times during this period to account for temporal variation. Survey sections and dates are shown in Table 2.

A team of two people conducted surveys by walking in an upstream direction with one person walking each side of the stream. Surveyors marked each new redd observed with flagging and recorded the date, redd number, and a size estimate and number of live bull trout observed.

Table 2. Bull trout redd survey location, distance (if applicable), and dates each location was surveyed in 2002.

\begin{tabular}{|c|c|c|c|}
\hline Sub-basin & Survey Location & Distance $(\mathrm{km})$ & Survey Date \\
\hline McKenzie: & $\begin{array}{l}\text { Anderson Cr. (Index) } \\
\text { Anderson Cr. (Total) } \\
\text { Olallie Creek } \\
\text { Sweetwater Creek } \\
\text { Upper McKenzie }\end{array}$ & $\begin{array}{c}1.3 \\
2.6^{\mathrm{a}} \\
1.9 \\
1.9 \\
1.1\end{array}$ & $\begin{array}{l}8 / 28,9 / 11,9 / 26,10 / 8 \\
10 / 24 \\
8 / 28,9 / 11,9 / 26,10 / 8 \\
10 / 15,10 / 24 \\
8 / 29,9 / 12,9 / 25,10 / 9\end{array}$ \\
\hline Middle Fork: & $\begin{array}{l}\text { Iko Springs } \\
\text { Chuckle Springs } \\
\text { Indigo Springs } \\
\text { Skunk Creek } \\
\text { Found Creek } \\
\text { Swift Creek }\end{array}$ & & $\begin{array}{l}9 / 3,9 / 18,9 / 30 \\
9 / 3,9 / 18,9 / 30 \\
9 / 3,9 / 18,9 / 30 \\
9 / 4,9 / 16,10 / 1 \\
9 / 4,9 / 16,10 / 1 \\
9 / 16\end{array}$ \\
\hline South Fork: & Roaring River & 2.7 & $9 / 10,9 / 23,9 / 26,10 / 02$ \\
\hline
\end{tabular}

\footnotetext{
${ }^{\mathrm{a}}$ The previously reported distance was $2.4 \mathrm{~km}$ but has been updated to $2.6 \mathrm{~km}$
} 


\section{RESULTS}

\section{Anderson Creek Screw Trap}

The Anderson Creek screw trap captured 508 bull trout fry and 131 age 1 and older juvenile bull trout. We estimated that 1,453 fry and 397 age $1+$ bull trout migrated past the Anderson Creek screw trap to the main stem McKenzie during the sampling period (Table 3). The number of fry estimated in 2002 was the lowest since the first full trapping season in 1994, however, the age $1+$ bull trout estimate was similar to previous estimates (Figure 2).

Table 3. The number of bull trout fry and juveniles (age 1 and older) captured in the downstream migrant screw trap in Anderson Creek from 1994 to 2001.

\begin{tabular}{lccccc}
\hline & \multicolumn{3}{c}{ Fry } & & \multicolumn{2}{c}{ Age 1 and Older } \\
\cline { 2 - 3 } \cline { 5 - 6 } Date & Captured & Estimated & & Captured & Estimated \\
\hline Feb. 15- May 26, 1994 & 1,745 & 5,827 & & 183 & 753 \\
Feb. 15- May 31, 1995 & 1,849 & 6,097 & & 255 & 773 \\
Feb. 19- May 31, 1996 & 1,995 & 5,700 & & 178 & 475 \\
Feb. 11- May 31, 1997 & 7,260 & 21,607 & & 63 & 205 \\
Feb. 10- June 11, 1998 & 7,869 & 23,053 & & 124 & 417 \\
Feb. 23- June 03, 1999 & 7,406 & 21,698 & & 81 & 255 \\
Feb. 21- May 25, 2000 & 6,127 & 17,750 & & 152 & 455 \\
Feb. 19- May 3, 2001 & 3,247 & 9,853 & & 82 & $238^{\text {a }}$ \\
Feb. 12- May 31, 2002 & 508 & 1,453 & & 131 & 397 \\
\hline
\end{tabular}

a2001 was not a complete sample year for age $1+$ bull trout due to trap repairs

\section{Middle Fork Willamette Re-Introduction}

We transferred 290 bull trout fry captured in the Anderson Creek screw trap to the Middle Fork Willamette release sites. Fry were released into Chuckle Springs, Iko Springs, and Bear Creek in 2002 (Table 4). A total of 8,187 bull trout fry have been released into the Middle Fork since 1997.

Table 4. Location and number of bull trout fry transferred from Anderson Creek to release sites in the Middle Fork Willamette above Hills Creek Reservoir from 1997 to 2002.

\begin{tabular}{|c|c|c|c|c|c|c|c|c|c|}
\hline & \multicolumn{4}{|c|}{ Springs } & \multicolumn{4}{|c|}{ Creeks } & \multirow[b]{2}{*}{ Total } \\
\hline & Chuckle & Iko & Indigo & Shadow & Bear & Swift & Found & Skunk & \\
\hline 1997 & 96 & & 26 & & & & & 56 & 178 \\
\hline 1998 & 411 & 938 & & 150 & & & & & 1,497 \\
\hline 1999 & 302 & 1,000 & & 148 & & 526 & & & 1,978 \\
\hline 2000 & 349 & 1,075 & 204 & 53 & & 822 & 285 & & 2,788 \\
\hline 2001 & 269 & 418 & & & 673 & 96 & & & 1,456 \\
\hline 2002 & 177 & 75 & & & 38 & & & & 290 \\
\hline Total & 1,604 & 3,506 & 230 & 351 & 711 & 1,444 & 285 & 56 & \\
\hline
\end{tabular}




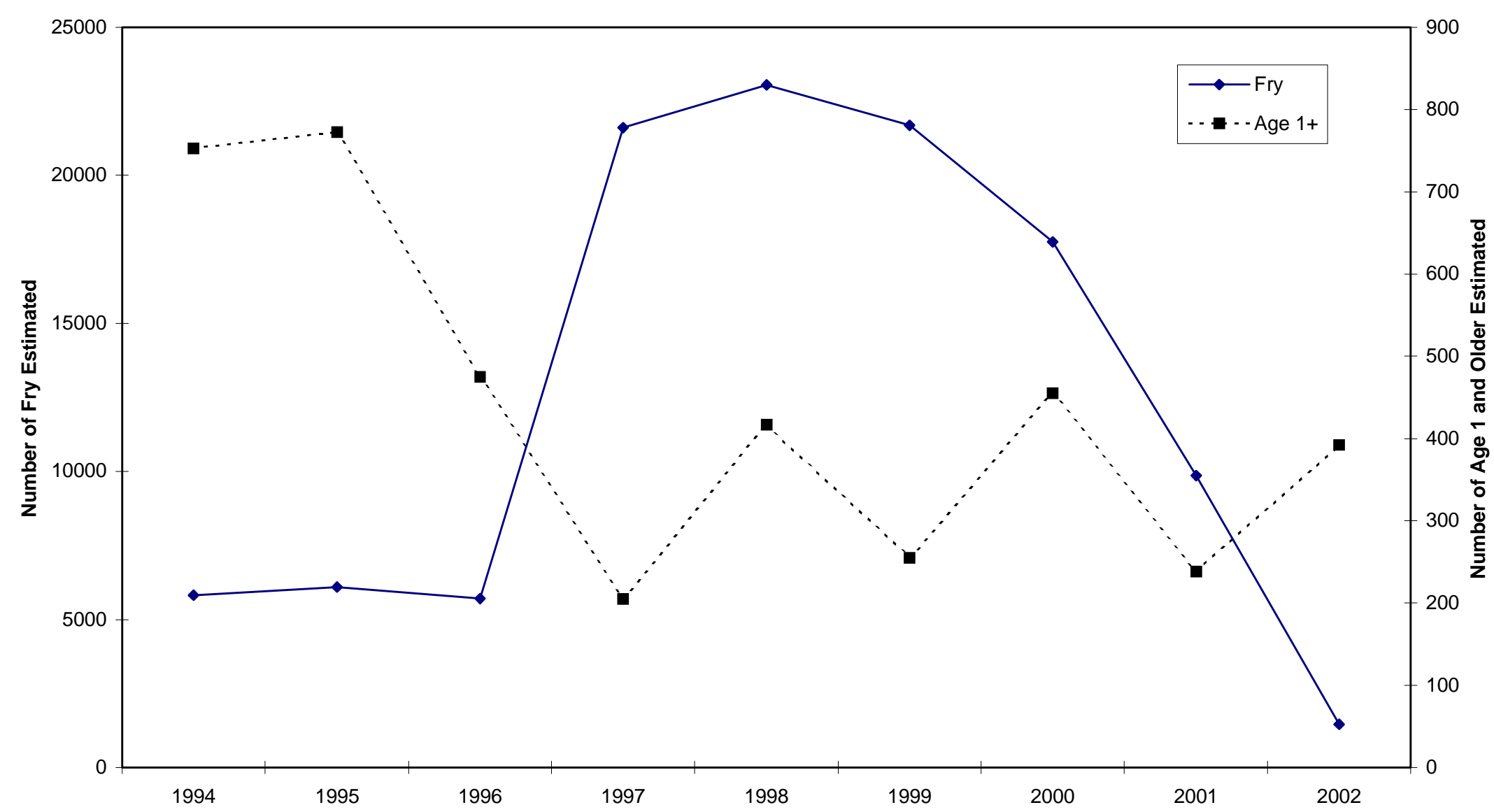

Figure 2. Number of fry and age 1+ juvenile bull trout caught in the Anderson Creek screw trap from 1994 to 2002. 


\section{Middle Fork Willamette Population Monitoring}

Minnow traps captured a total of four juvenile bull trout that ranged in fork length from 87- $150 \mathrm{~mm}$. The single bull trout captured in Found Creek measured $150 \mathrm{~mm}$ in length and was likely a two year old fish from the 2000 fry release into Found Creek. Two bull trout captured in Shadow Springs were $104 \mathrm{~mm}$ and $117 \mathrm{~mm}$ in length and were likely age two or older from the three fry releases of 1998-2000. The one bull trout captured in the Indigo Springs side channel measured $87 \mathrm{~mm}$ long and was likely a two year old from the 2000 fry release.

Snorkelers observed a total of 6 bull trout ranging in length from $130 \mathrm{~mm}$ to $300 \mathrm{~mm}$. One bull trout was observed in Chuckle Springs on 9 July. Five bull trout were observed near the mouth of Found Creek during a night snorkel on 31 July (Appendix A).

\section{Vaki Riverwatcher Fishcounter and Video Analysis in Anderson Creek, Olallie Creek, Sweetwater Creek and Roaring River}

The Riverwatcher recorded 287 adults in Anderson Creek, 82 adults in Roaring River, and 10 adults in Olallie Creek passing upstream. The Anderson Creek count was the highest recorded by the Vaki since it was installed in 1999 (Table 5).

Table 5. Number of fish moving upstream recorded by the Riverwatcher in Anderson Creek and Roaring River from 1999 to 2002, and in Olallie Creek in 2002.

\begin{tabular}{|c|c|c|c|}
\hline & \multicolumn{3}{|c|}{ Count of Upstream Migrants } \\
\hline & Anderson $\mathrm{Cr}$. & Roaring River & Olallie Cr. \\
\hline 1999 & 249 & 41 & - \\
\hline 2000 & 138 & $86^{\mathrm{a}}$ & - \\
\hline 2001 & $87^{\mathrm{a}}$ & $67^{\mathrm{a}}$ & - \\
\hline 2002 & 287 & 82 & 10 \\
\hline
\end{tabular}

Length frequency distribution of fish passing upstream of each Riverwatcher site varied between the main stem McKenzie tributaries and Roaring River. The mean length of Roaring River bull trout was much larger than mean lengths of Anderson and Olallie Creek bull trout (Table 6).

Table 6. Estimated range and mean length in millimeters of bull trout passing upstream of a Vaki Riverwatcher Fishcounter in Anderson Creek ( $\mathrm{n}=287$ ), Roaring River $(\mathrm{n}=82)$, and Olallie Creek in 2002 $(\mathrm{n}=10)$

\begin{tabular}{cccc}
\hline & Anderson Cr. & Roaring River & Olallie Cr. \\
\cline { 2 - 4 } Range & $184-736$ & $190-960$ & $239-635$ \\
Mean & 395 & 661 & 365 \\
\hline
\end{tabular}

Length frequencies of upstream adult migrants in Anderson Creek resulted in even distribution of length classes less than $60 \mathrm{~cm}$ but were lower in percentage of length classes greater than $61 \mathrm{~cm}$ in 2002 (Figure 3). The number of upstream bull trout in 
length classes greater than $61 \mathrm{~cm}$ was $1.3 \%$ in 2002, which was lower than the $16.1 \%$ average from 1999-2001.

In Roaring River, percent frequency of upstream adult migrants in large length classes continued to increase in 2002 (Figure 4). The number of bull trout in the length class greater than $61 \mathrm{~cm}$ was $77 \%$ of the total upstream count.

Daily time periods in which bull trout migrated upstream were similar in Roaring River and Anderson Creek. In Anderson Creek, peak daily upstream and downstream migration occurred from 11:00 to 20:00 hours (Figure 5). In Roaring River, peak daily upstream migration occurred from 10:00 to 18:00 hours while peak daily downstream migration occurred from 16:00 to 02:00 hours (Figure 6).

Migration of bull trout through the Riverwatcher began in mid-August and declined in late September in Anderson Creek and Roaring River. Peak upstream migration in Anderson Creek and Roaring River occurred in mid-September (Figures 7 and 8).

Downstream migration timing in Anderson Creek was similar to upstream migration timing while peak downstream migration in Roaring River was about 10 days after peak upstream migration.

The video camera in Anderson Creek confirmed 135 (66\%) of the 206 fish that passed upstream through the Riverwatcher from 9 September to 5 October were bull trout. All of the fish recorded by the Riverwatcher during daylight hours and observed on the video were confirmed to be bull trout. 

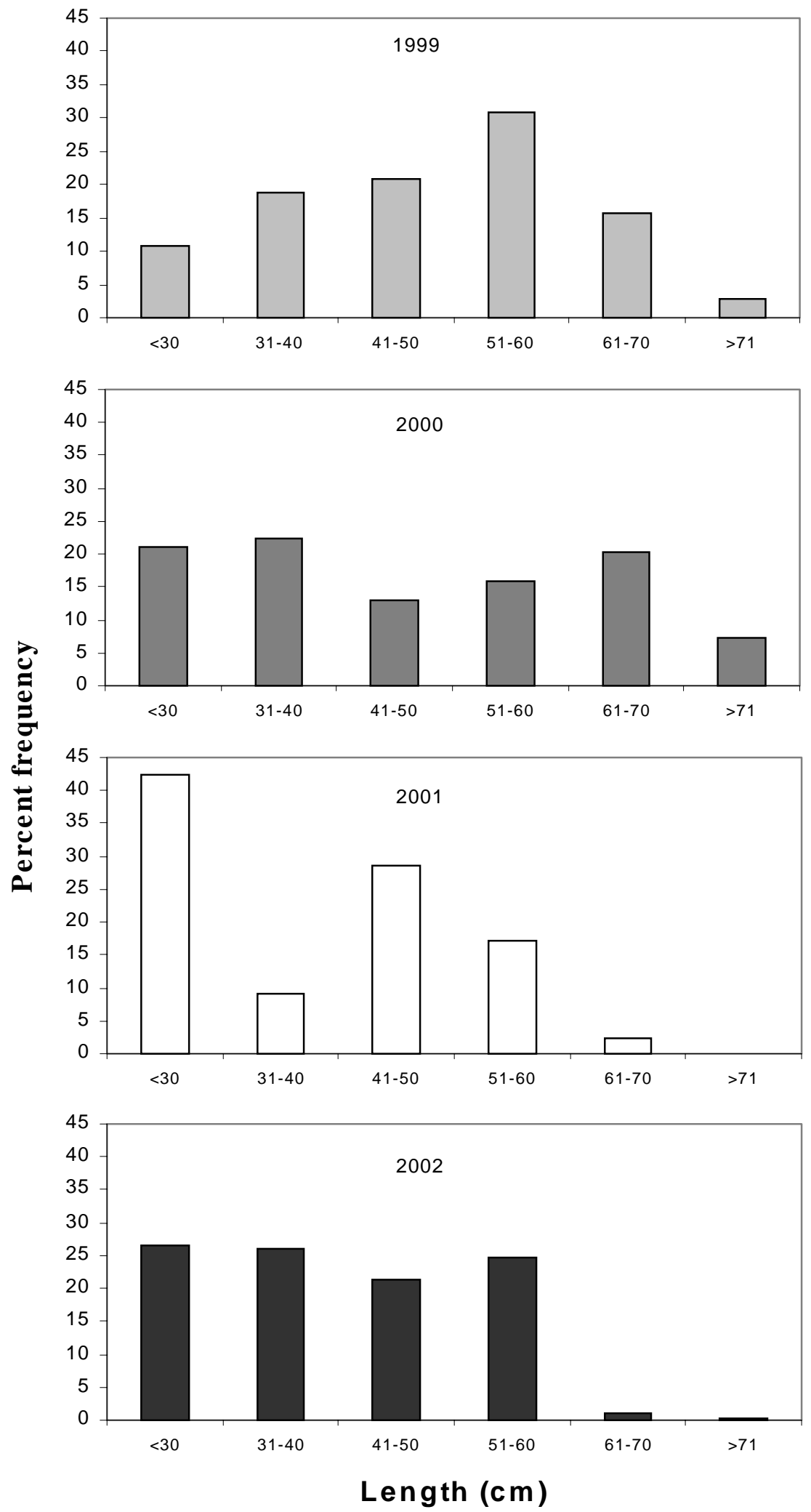

Figure 3. Length frequency distribution of fish passing upstream through the Vaki Riverwatcher in Anderson Creek from 1999 to 2002. Individual bars represent the percent of fish counted that were in each length class for 1999, 2000, 2001, and 2002. 

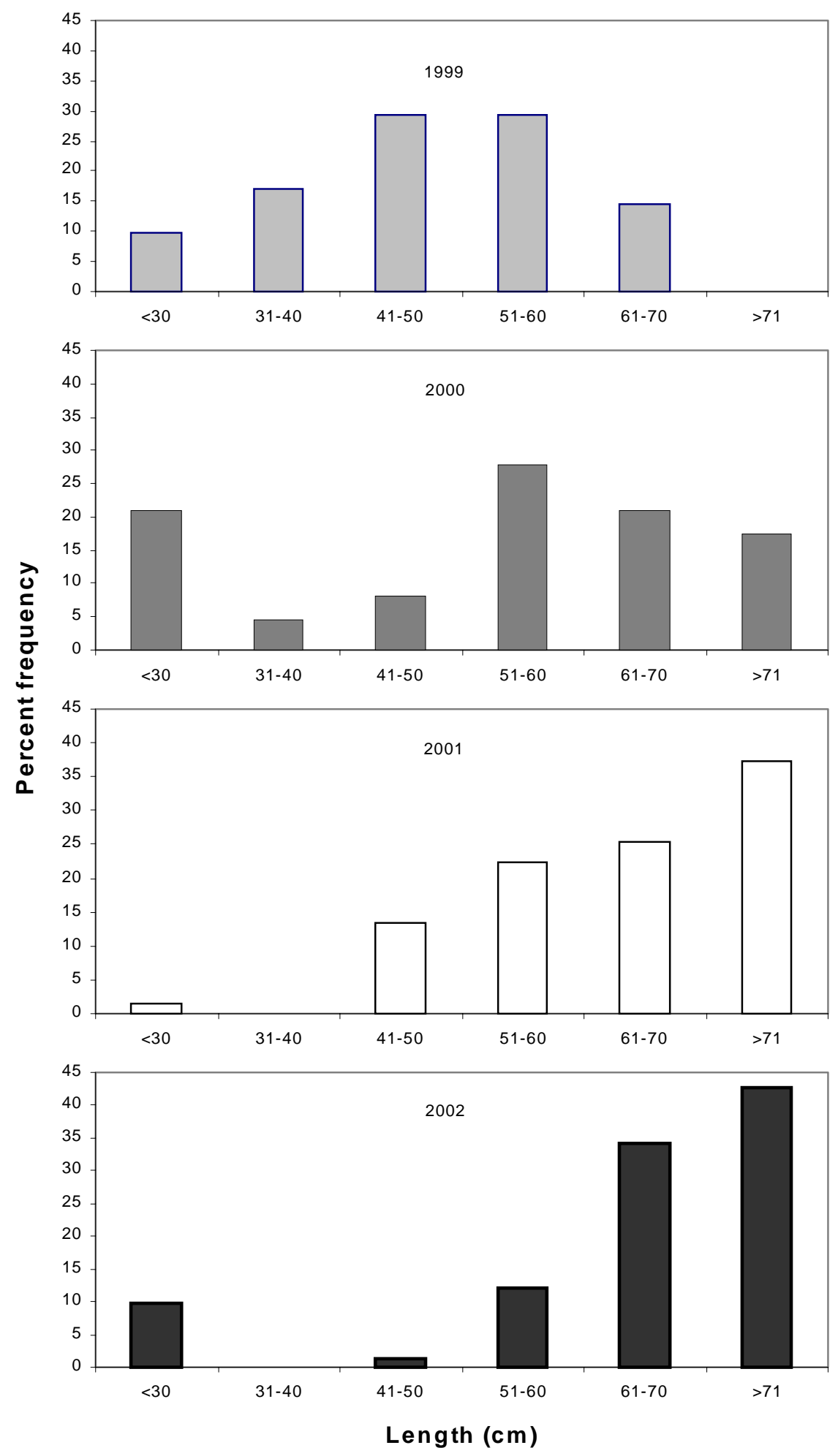

Figure 4. Length frequency distribution of fish moving upstream through the Vaki Riverwatcher in Roaring River from 1999 to 2002. Individual bars represent the percentage of total fish counted that were in each length class for 1999, 2000, 2001, and 2002. 


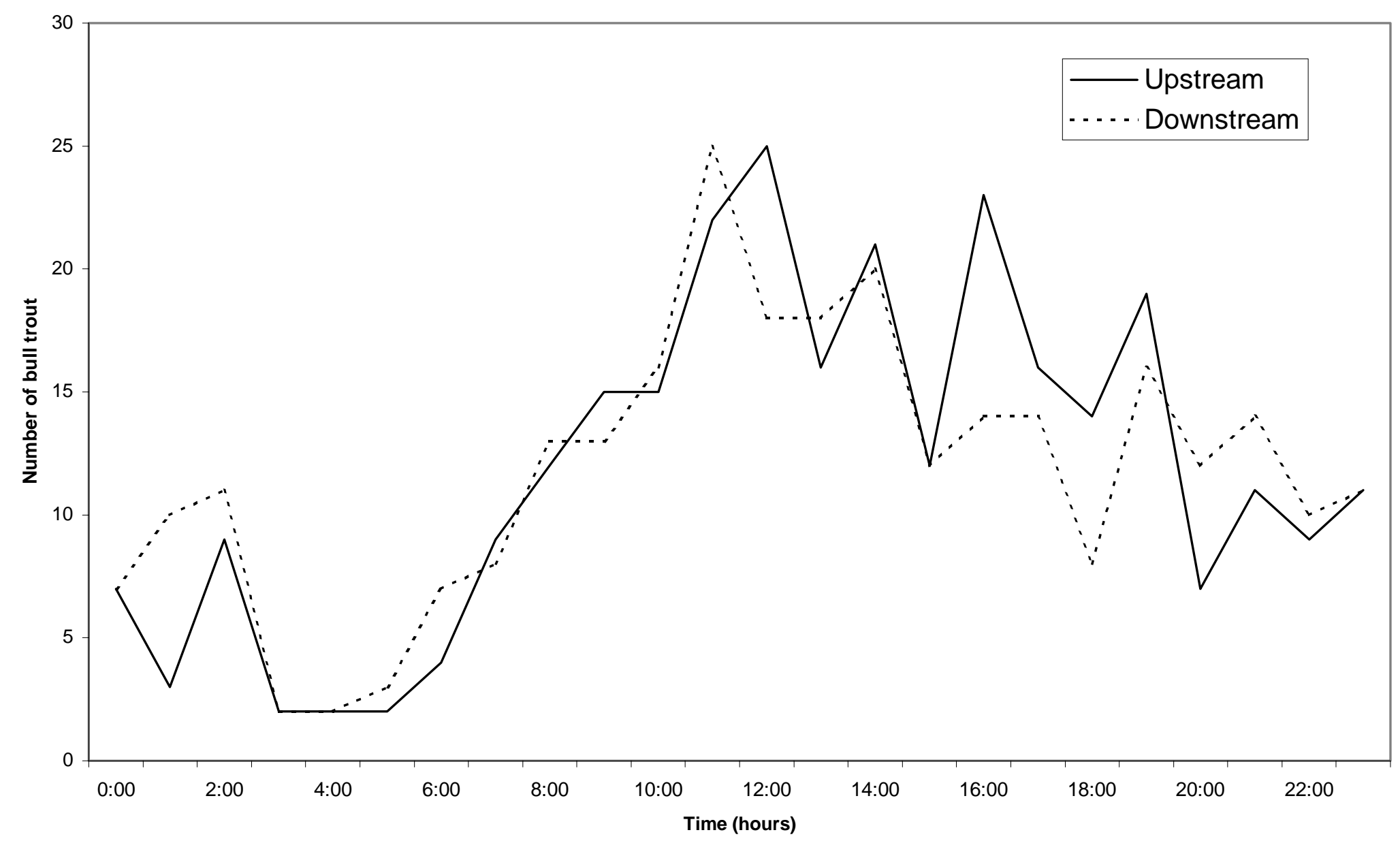

Figure 5. Diel movement of fish through the Vaki Riverwatcher in Anderson Creek during the 2002 migration period. Time is represented from 0:00 hours to 24:00 hours from 13 August to 4 November 2002. 


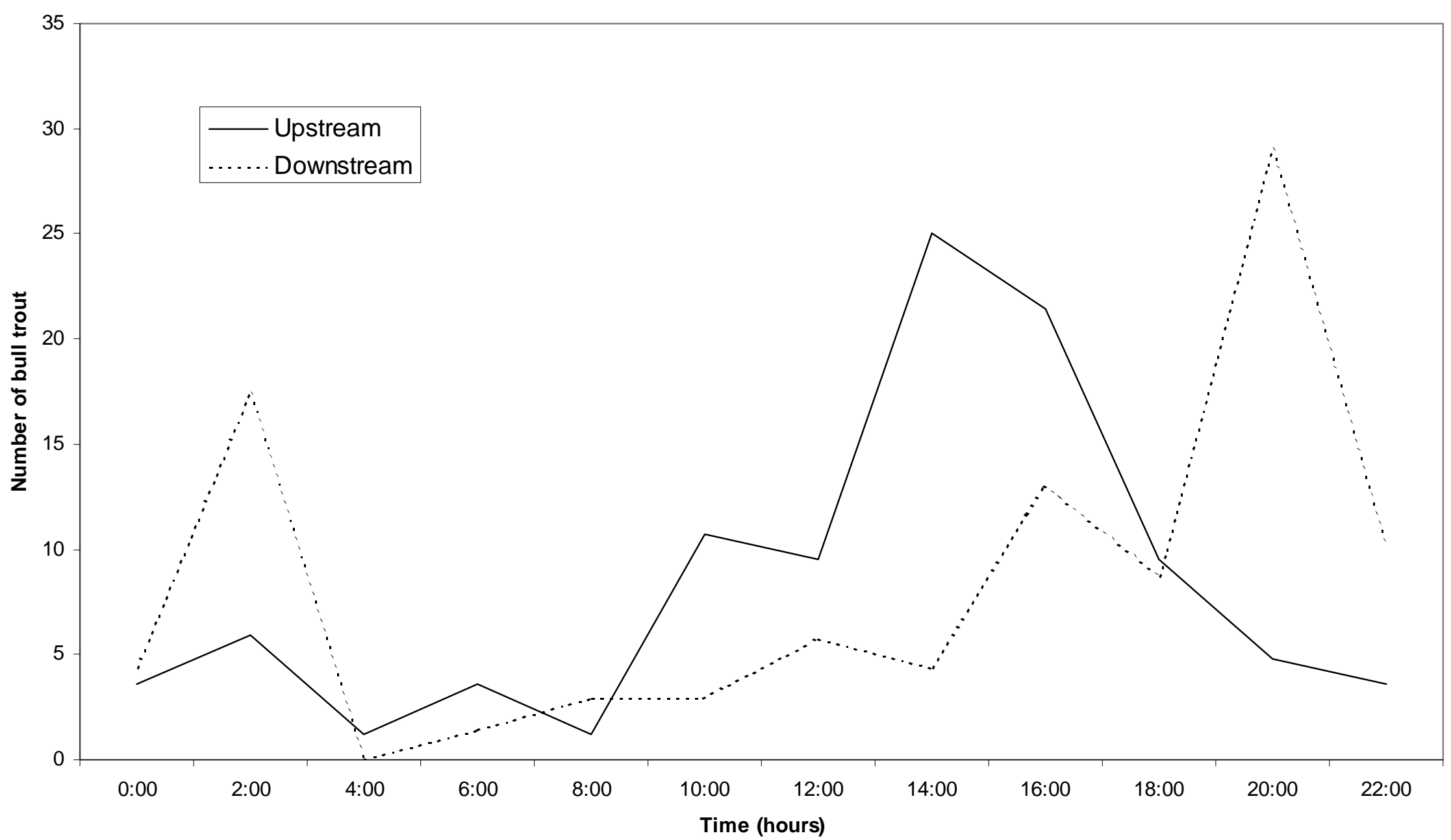

Figure 6. Diel movement of fish through the Vaki Riverwatcher in Roaring River during the 2002 migration period. Time is represented from 0:00 hours to 24:00 hours from 16 August to 8 October 2002. 


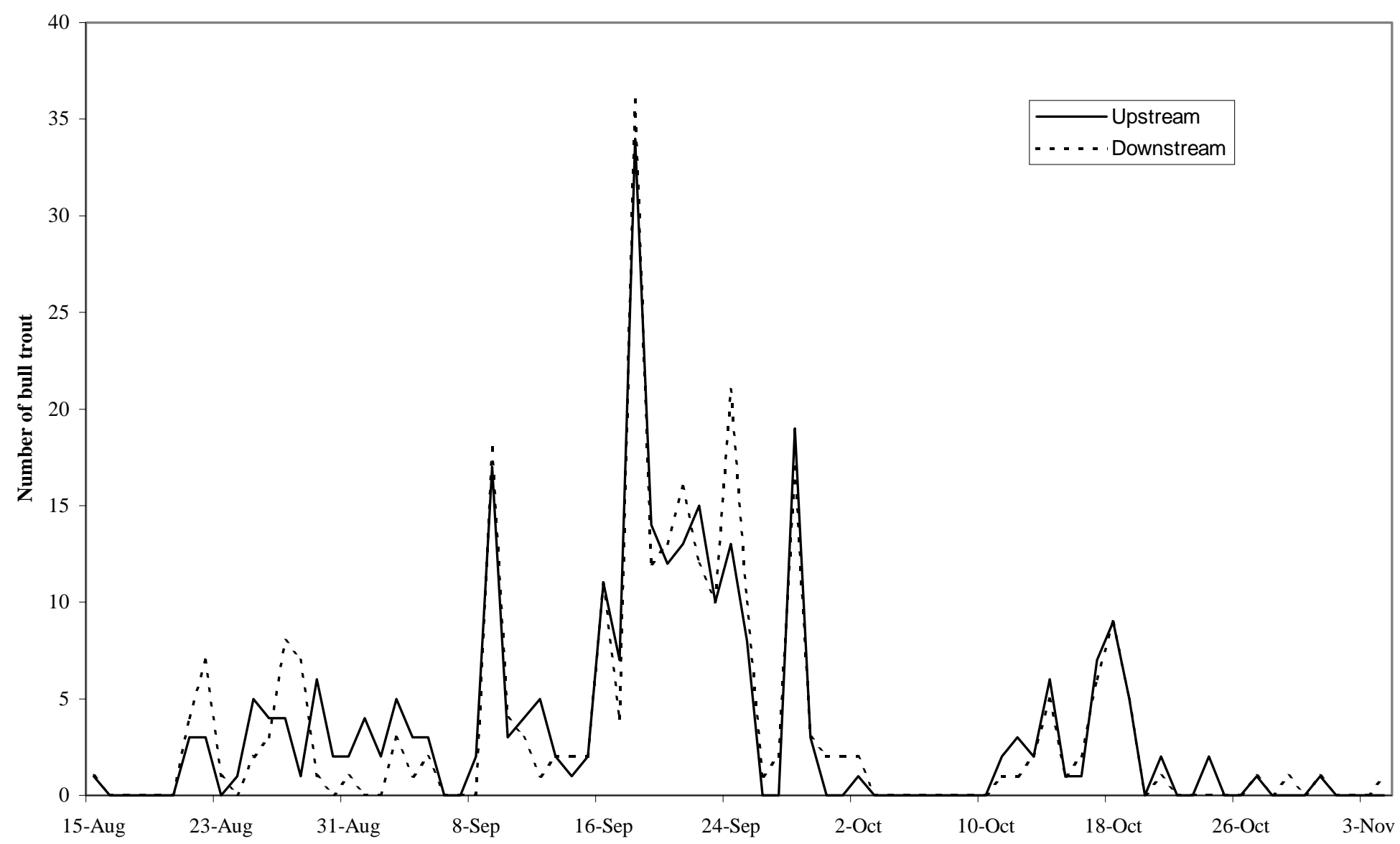

Figure 7. Migration timing of bull trout through the Vaki Riverwatcher in Anderson Creek from 13 August to 4 November 2002. 


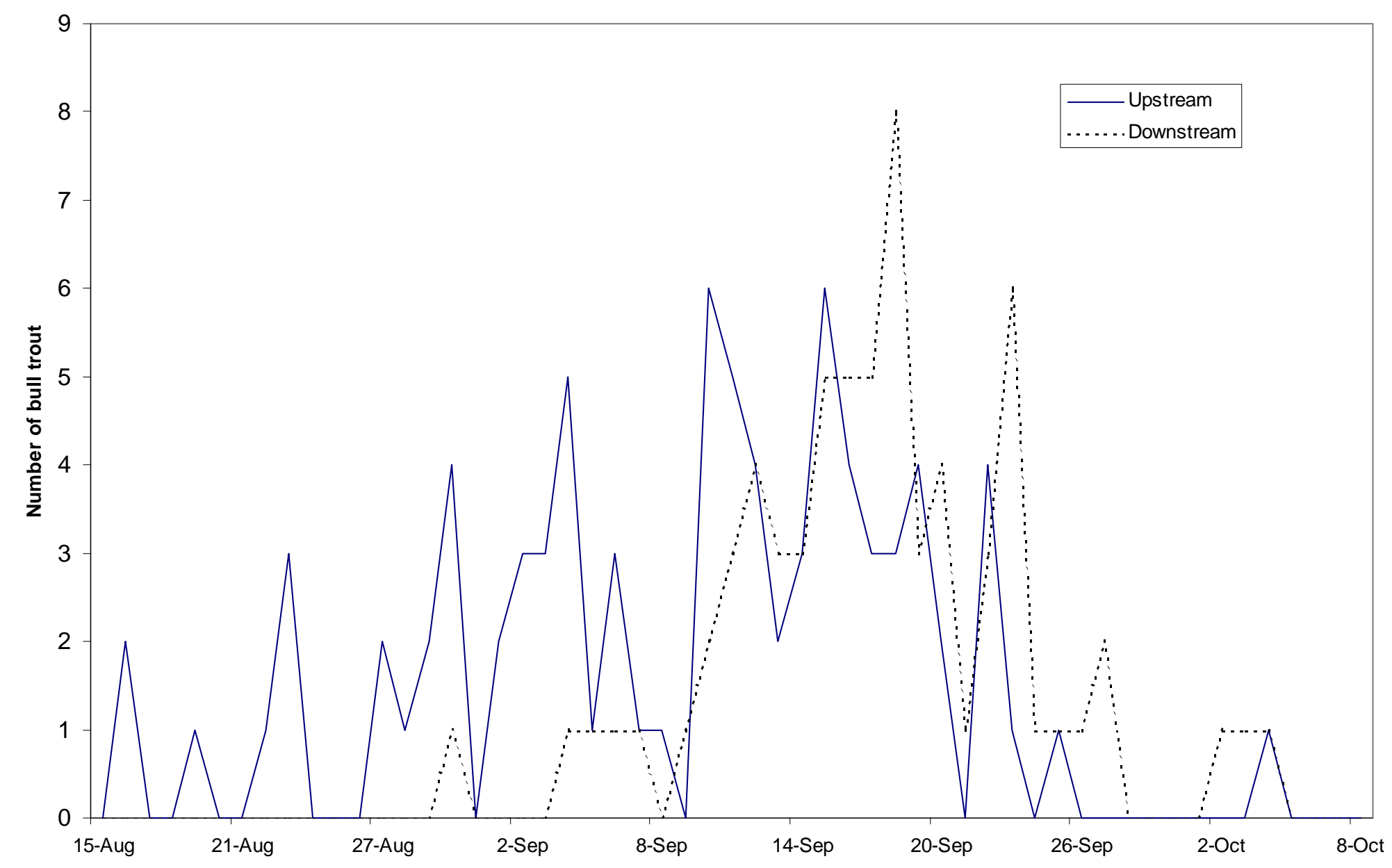

Figure 8. Migration timing of bull trout through the Vaki Riverwatcher in Roaring River from 15 August to 8 October 2002. 


\section{Bull Trout Spawning Surveys}

During Fall 2002, surveyors counted 99 bull trout redds in the McKenzie River basin and no redds in the Middle Fork Willamette basin. The number of redds counted in Anderson Creek and Roaring River were fewer than in 2001 while redds in Olallie Creek and the main stem McKenzie increased from previous counts (Table 7). The average number of redds per kilometer were 23.1 in Anderson Creek, 5.3 in Olallie Creek, 2.7 in the main stem McKenzie above Trailbridge Reservoir, 0.5 in Sweetwater Creek, and 9.3 in Roaring River.

Table 7. Number of bull trout redds enumerated in Anderson Creek, Olallie Creek, main stem McKenzie, Sweetwater Creek, and Roaring River, 1989 to 2002.

\begin{tabular}{|c|c|c|c|c|c|c|c|}
\hline & \multicolumn{2}{|c|}{ Anderson } & \multirow[t]{2}{*}{ Olallie } & \multirow[t]{2}{*}{ McKenzie } & \multirow[t]{2}{*}{ Sweetwater } & \multirow[t]{2}{*}{ Roaring } & \multirow[t]{2}{*}{ Basin Total } \\
\hline & $\begin{array}{c}\text { Index } \\
\text { Area }\end{array}$ & Total & & & & & \\
\hline Year & & & & & & & \\
\hline 1989 & 7 & - & - & - & - & - & - \\
\hline 1990 & 9 & - & - & - & - & - & - \\
\hline 1991 & 7 & - & - & - & - & - & - \\
\hline 1992 & 13 & - & - & - & - & - & - \\
\hline 1993 & 15 & - & - & - & - & 1 & - \\
\hline 1994 & 22 & 30 & - & 0 & - & 1 & - \\
\hline $1995^{\mathrm{a}}$ & 30 & 74 & 10 & 7 & - & 2 & 93 \\
\hline 1996 & 26 & 82 & 7 & 7 & - & 0 & 96 \\
\hline 1997 & 18 & 85 & 9 & 3 & - & 0 & 97 \\
\hline 1998 & 29 & 79 & 7 & 2 & - & 6 & 94 \\
\hline 1999 & 47 & 77 & 6 & 0 & - & 13 & 96 \\
\hline 2000 & 44 & 83 & 9 & 0 & 2 & 25 & 119 \\
\hline 2001 & 23 & 72 & 6 & 0 & 2 & 34 & 114 \\
\hline 2002 & 31 & 60 & 10 & 3 & 1 & 25 & 99 \\
\hline
\end{tabular}




\section{DISCUSSION}

The 508 bull trout fry captured during 2002 in the Anderson Creek screw trap were progeny of the spawning that created 72 redds counted in 2001. The 2001 redd count was above the 9 year average (1994- 2002) of 71.3 redds. We are not sure why such low numbers of fry were captured in 2002. Potentially, several factors could have contributed to low fry densities:

1) Changes in water temperature could have caused poor egg incubation and hatching success.

2) If the average size of females was smaller than previous years, the number of eggs deposited in gravel may have been lower.

3) Also, smaller females would likely have shallower redds possibly resulting in poor incubation.

The abundance of fry captured in the screw trap does not always correspond to the abundance of age 1+ bull trout captured the following year (Figure 2). For example, in 1994 we captured 1808 fry and 261 age 1+ bull trout in 1995. Also, in 1998 we captured 7902 fry and 100 age $1+$ bull trout in 1999. It is possible that the juvenile bull trout rearing habitat of Anderson Creek may be fully seeded every year and the excess fry emigrate to the McKenzie. Hence, these excess fry may essentially be what the screw trap captures while the remaining fry rear in Anderson Creek. With such low fry capture in 2002, we will evaluate the number of age 1+ bull trout captured during the 2003 migration period. If age $1+$ bull trout capture remains consistent in 2003 after such a poor fry capture year in 2002, we may be able to deduce that low densities of fry do not always produce low numbers of age 1+ bull trout in Anderson Creek. Survival of bull trout fry that emigrate from Anderson Creek to the main stem McKenzie is unknown.

The Riverwatcher is not an accurate tool for estimating the Anderson Creek bull trout population. The number of upstream migrant bull trout in Anderson Creek that the Riverwatcher records does not correspond with the number of redds counted in Anderson Creek. Although redd counts in Anderson Creek were slightly down in 2002 from previous years, the Anderson Creek Riverwatcher recorded the highest number of upstream migrants since the Riverwatcher was installed in 1999 (Table 8). In contrast, the Riverwatcher recorded only 87 upstream migrants and surveyors counted 72 redds in 2001. Although we assume most of the bull trout that pass through the Riverwatcher are spawners, we do not know how many are non-spawners following other bull trout. It is also likely that some bull trout are being counted multiple times by moving upstream and downstream through the Vaki before or during spawning. The current location of the Riverwatcher is in a pool below a culvert where bull trout may hold and move through the counter multiple times. We believe that by moving the Riverwatcher to a site with higher gradient bull trout are less likely to swim up and down in such water.

Adult spring chinook salmon were observed during a spawning survey in Roaring River above the Riverwatcher site. These fish passed through the Riverwatcher and were counted as bull trout because the Riverwatcher is unable to distinguish between chinook 
salmon and bull trout. The Cougar Research Project plans to install an underwater video system to observe fish moving through the Vaki in 2003.

The underwater video camera gathered valuable information because it verified fish recorded by the Riverwatcher as bull trout in Anderson Creek. Although numerous cutthroat trout were observed on the video, no cutthroat were recorded by the Riverwatcher while the video was operating. We suggest that the video be used more extensively in the future to sample during the entire migration period and possibly during nighttime hours.

Although no redds were observed in areas surveyed on the Middle Fork, we suspect there will be sexually mature bull trout in 2003. Leary et al. (1993) reported that migratory bull trout begin spawning at Age 5 to Age 6 and Pratt (1991) determined that most adult bull trout in the Metolius River begin spawning at Age 5. The first large release of bull trout fry into areas of the Middle Fork was in 1998 (Table 4). Fry from the 1998 release will be age 5 and may be sexually mature in 2003.

\section{ACKNOWLEDGEMENTS}

We would like to thank the Bonneville Power Administration, Willamette National Forest (WNF) and ODFW for providing primary funding for this project. Thanks to Dave Bickford and the McKenzie Ranger District staff WNF, Doug Larson and the Middle Fork Ranger District staff WNF, Doug Garletts and Greg Taylor from the Army Corps of Engineers, Mark Wade, Vince Tranquilli, Chad Helms, Jeff Ziller, and staff at the ODFW Springfield District Office for contributing effort and information for this project. 


\section{REFERENCES}

Buchanan, D.V., M.L. Hanson, and R.M. Hooton. 1997. Status of Oregon's Bull Trout. Oregon Department of Fish and Wildlife, Portland.

Connolly, P.C, M.G. Wade, J.M. Hutchison, and J.S. Ziller. 1992. Middle Fork Willamette Subbasin Fish Management Plan. Oregon Department of Fish and Wildlife, Portland.

Goetz, F.A. 1994A. Biology of the bull trout, Salvelinus confluentus, a literature review. U.S. Department of Agriculture, Forest Service, Willamette National Forest, Eugene, Oregon.

Goetz, F.A. 1994B. Distribution and Juvenile Ecology of Bull Trout (Salvelinus confluentus) in the Cascade Mountains. Oregon State University. Thesis: 65.

Howell, P. J., J. Hutchinson, and R. Hooton. 1988. McKenzie Subbasin Fish Management Plan. Oregon Department of Fish and Wildlife, Portland.

ODFW and USFS. 1997. Rehabilitation of the Middle Fork Willamette Bull Trout Population, Risk Analysis and Monitoring Plan. U.S. Department of Agriculture, Forest Service, Rigdon Ranger District, Oregon Department of Fish and Wildlife, Springfield District Office, Springfield, OR.

Leary, R.F., F.W. Allendorf, and S.H. Forbes. 1993. Conservation genetics of bull trout in the Columbia and Klamath River drainages. Conservation Biology 7 (4):856-865.

Pratt, K.L. 1991. Bull trout scale analysis for the Metolius River Basin. Final Report. U.S. Forest Service Deschutes National Forest, Bend, Oregon.

Ratliff, D.E., and P.J. Howell. 1992. Status of Bull Trout in Oregon. Pages 10-17 in P.J. Howell and D.V. Buchanan, editors. Proceedings of the Gearhart Mountain Bull Trout Workshop. Oregon Chapter of the American Fisheries Society, Corvallis.

Ratliff, D.E. S.L. Thiesfeld, W.G. Weber, A.M. Stuart, M.D. Riehle, and D.V. Buchanan. 1996. Distribution, life history, abundance, harvest, habitat and limiting factors of bull trout in the Metolius River and Lake Billy Chinook, Oregon, 1983-94. Information Report, Oregon Department of Fish and Wildlife, Portland. 
Appendix A. Date, pool location, and fish observed for standard pool counts in the Middle Fork Willamette River basin for 2002.

\begin{tabular}{|c|c|c|c|}
\hline Date & Pools Sampled & $\begin{array}{l}\text { Number of Bull Trout } \\
\text { Observed }\end{array}$ & $\begin{array}{l}\text { Other Species } \\
\text { Observed }\end{array}$ \\
\hline \multirow[t]{7}{*}{$6 / 5$} & Head of Reservoir & 0 & Rb,ChS,CSU \\
\hline & 1 & 0 & $\mathrm{Rb}, \mathrm{WF}$ \\
\hline & 2 & 0 & CSU \\
\hline & 3 & 0 & $\mathrm{Rb}, \mathrm{COT}$ \\
\hline & 4 & 0 & $\mathrm{Rb}, \mathrm{CSU}$ \\
\hline & 5 & 0 & $\mathrm{Rb}, \mathrm{CT}, \mathrm{CSU}$ \\
\hline & 8 & 0 & $\mathrm{Rb}, \mathrm{CSU}$ \\
\hline \multirow[t]{4}{*}{$6 / 10$} & 10 & 0 & $\mathrm{Rb}, \mathrm{ChS}, \mathrm{CT}, \mathrm{COT}$ \\
\hline & 11 & 0 & $\mathrm{CT}$ \\
\hline & 12 & 0 & $\mathrm{Rb}, \mathrm{ChS}, \mathrm{CT}, \mathrm{WF}$ \\
\hline & 13 & 0 & $\mathrm{ChS,CT}$ \\
\hline \multirow[t]{6}{*}{$6 / 25$} & Head of Reservoir & 0 & $\mathrm{Rb}, \mathrm{CSU}, \mathrm{COT}$ \\
\hline & 1 & 0 & $\mathrm{Rb}, \mathrm{CT}, \mathrm{ChS}$ \\
\hline & 2 & 0 & $\mathrm{Rb}, \mathrm{CT}, \mathrm{WF}, \mathrm{CSU}$ \\
\hline & 3 & 0 & $\mathrm{Rb}, \mathrm{CT}, \mathrm{WF}, \mathrm{CSU}$ \\
\hline & 4 & 0 & $\mathrm{Rb}, \mathrm{ChS}$ \\
\hline & 6 & 0 & $\mathrm{Rb}, \mathrm{ChS}, \mathrm{CT}, \mathrm{WF}, \mathrm{CSU}$ \\
\hline $7 / 2$ & Lower Half Float & 0 & $\mathrm{Rb}, \mathrm{ChS}, \mathrm{CT}, \mathrm{WF}, \mathrm{COT}$ \\
\hline \multirow[t]{6}{*}{$7 / 9$} & 6 & 0 & $\mathrm{Rb}, \mathrm{ChS}, \mathrm{CT}, \mathrm{WF}, \mathrm{CSU}, \mathrm{COT}$ \\
\hline & 7 & 0 & $\mathrm{Rb}, \mathrm{ChS}, \mathrm{CT}$ \\
\hline & 8 & 0 & $\mathrm{Rb}, \mathrm{ChS}, \mathrm{CT}, \mathrm{WF}$ \\
\hline & 11 & 0 & $\mathrm{ChS}, \mathrm{CT}$ \\
\hline & 12 & 0 & $\mathrm{CT}$ \\
\hline & 13 & 1 & $\mathrm{Rb}, \mathrm{CT}, \mathrm{BT}$ \\
\hline \multirow[t]{7}{*}{$7 / 22$} & 1 & 0 & $\mathrm{Rb}, \mathrm{WF}$ \\
\hline & 2 & 0 & $\mathrm{Rb}, \mathrm{WF}, \mathrm{CSU}$ \\
\hline & 3 & 0 & $\mathrm{Rb}, \mathrm{CT}$ \\
\hline & 4 & 0 & $\mathrm{Rb}, \mathrm{CT}, \mathrm{WF}$ \\
\hline & 5 & 0 & $\mathrm{Rb}, \mathrm{CT}, \mathrm{WF}$ \\
\hline & 6 & 0 & $\mathrm{Rb}, \mathrm{ChS}, \mathrm{CT}, \mathrm{WF}, \mathrm{CSU}$ \\
\hline & Upper Sacandaga CG & 0 & $\mathrm{Rb}, \mathrm{ChS}, \mathrm{CT}$ \\
\hline $7 / 31$ & 11 & 5 & Data not recorded \\
\hline
\end{tabular}

